\title{
Late Quaternary sea-level change and isostatic and tectonic land movements along the Belgian-Dutch North Sea coast: geological data and model results
}

\author{
P. KIDEN, ${ }^{1 *}$ L. DENYS ${ }^{2}$ and P. JOHNSTON ${ }^{3+}$ \\ ${ }^{1}$ Netherlands Institute of Applied Geoscience TNO - National Geological Survey, Department of Geo-Infrastructure, \\ Princetonlaan 6, P.O. Box 80015, NL-3508 TA Utrecht, The Netherlands \\ ${ }^{2}$ Institute of Nature Conservation, Kliniekstraat 25, B-1070 Brussel, Belgium \\ ${ }^{3}$ Research School of Earth Sciences, Australian National University, Canberra ACT 0200, Australia
}

\begin{abstract}
Early and middle Holocene sea-level data from Belgium plot ca. $2 \mathrm{~m}$ above data from the western Netherlands, reflecting differential tectonic and isostatic movements. The total uplift rate of Belgium relative to the western Netherlands decays gradually from $0.66 \mathrm{~m} \mathrm{kyr}^{-1}$ at $7500 \mathrm{cal}$. $\mathrm{yr} \mathrm{BP}$ to less than $0.25 \mathrm{~m} \mathrm{kyr}^{-1}$ since $5000 \mathrm{cal}$. $\mathrm{yr} \mathrm{BP}$. The tectonic component of this relative movement, inferred from Eemian sea-level data, is in the order of 0.06 to $0.16 \mathrm{~m} \mathrm{kyr}^{-1}$. The isostatic component of the uplift is related to the last phase of the collapse of a peripheral bulge under The Netherlands and the Dutch and German sectors of the North Sea, and to hydroisostatic subsidence of the North Sea basin caused by water loading as sea-level rose. Comparisons with isostatic rebound models show that they predict well the Holocene isostatic movement between Belgium and the western Netherlands, and that the predictions are improved when the tectonic component is removed from the observations. Preliminary evaluation of sea-level data from the Dutch sector of the North Sea shows that glacio-hydroisostatic subsidence relative to Belgium was significantly greater than for the western Netherlands coastal area, and spatially highly variable. Copyright @ 2002 John Wiley \& Sons, Ltd.
\end{abstract}

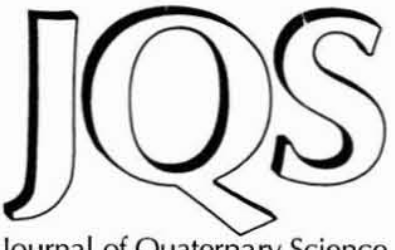

Journal of Quaternary Science

KEYWORDS: Late Quaternary sea-level change; isostasy; tectonics; isostatic models; North Sea.

\section{Introduction}

Quaternary sea-level histories from northwestern Europe reflect the influence of various eustatic, isostatic and tectonic factors operating on different temporal and spatial scales. Although the region around the North Sea has been the focus of a large number of highly detailed sea-level studies, discussion contilucs as to the magnitude and relative contribution of tectonic crustal movements and glacio- and hydroisostatic effects to the post-glacial sea-level history.

Most geophysical isostatic models clearly define the area of post-glacial rebound in Fennoscandia, surrounded by a subsiding zone, with the zone of greatest post-glacial subsidence (the so-called glacial forebulge or peripheral bulge)

*Correspondence to: P. Kiden, Netherlands Institute of Applied Geoscience TNO, Department of Geo-Infrastructure, Princetonlaan 6, P.O. Box 80015, NL3508 TA Utrecht, The Netherlands.

E-mail: p.kiden@nitg.tno.nl

tPresent address: Logica, 31 Ventnor Avenue, West Perth WA 6005, Australia situated in the North Sea between Norway and Great Britain, and extending through the northwestern Netherlands and northern Germany (Fjeldskaar, 1994; Lambeck, 1995). The transition between the central uplifting area and a peripheral zone of general subsidence is also evident from empirical sea-level studies (e.g. Mörner, 1979, 1980; Shennan, 1987). However, up to now the available sea-level data from the southern North Sea region has not allowed the definition of more detailed patterns of crustal movements within the subsiding areas, including the presence of a peripheral bulge. Identification of these patterns from sea-level data is mainly hampered by:

1. The lark of reliable 'old' (pre-8000 yr cal. BP) seaievol data from areas that have undergone post-glacial relative sea-level rise. Differential isostatic movements de _uy rapidiy after deglaciation and are thus best registered by lüte Weichselian or early Holocene sea-level indicators. However, in subsiding areas, sediments of this age are buried beneath a thick sequence of coastal deposits or are 
located in the present-day North Sea, which makes them difficult to locate and sample.

2. The difficulty of separating the effect of long-term tectonic subsidence or uplift from isostatic crustal movements, both of which are poorly understood. This is especially true in the eastern part of the southern North Sea, where tectonic subsidence and fault movements along the boundaries of major graben structures play an important role in the geological history of the region throughout the Cenozoic (Ziegler and Louwerens, 1979).

High-quality sea-level data from Belgium (Fig. 1) (Denys and Baeteman, 1995) offer an opportunity to partly solve these problems for the eastern coast of the southern North Sea. The data extend back in time to ca. $9000 \mathrm{cal}$. yr BP and plot consistently above comparable sea-level curves for the western Netherlands. Denys and Baeteman (1995) hypothesised that the relative height of the Belgian sea-level data with respect to those from the western Netherlands reflected considerable Holocene differential crustal movements between both regions, which are of glacio- and/or hydroisostatic origin. The Belgium-western Netherlands coastline of the North Sea is orientated almost perpendicular to the isobases around the Fennoscandian uplift centre, and is therefore optimally located to record post-glacial differential glacio-isostatic movements related to the glacial rebound of Fennoscandia (Fig. 2). That same transect is also located across the hinge line between the subsiding North Sea Basin towards the northwest and the tectonically more stable London-Brabant Massif to the south (Ziegler and Louwerens, 1979). Relative crustal movements between both countries are therefore likely to contain both an isostatic and a tectonic component.

It should be noted here that we will use the term 'isostasy' for crustal movements on a time-scale of $10^{3}-10^{4} \mathrm{yr}$ that are the result of ice and water loading or unloading owing to the

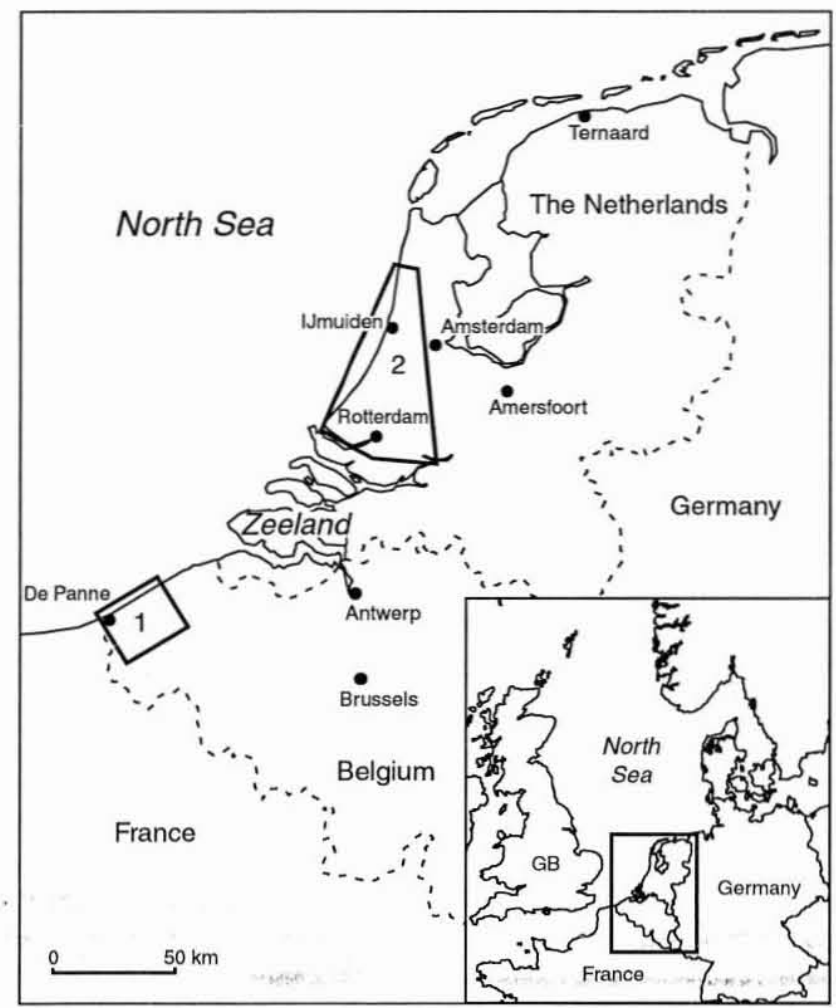

Figure 1 Location map of Belgium and The Netherlands with sites mentioned in the text. The study areas discussed here are: (1) western Belgian coastal plain and (2) coastal area of the western Netherlands

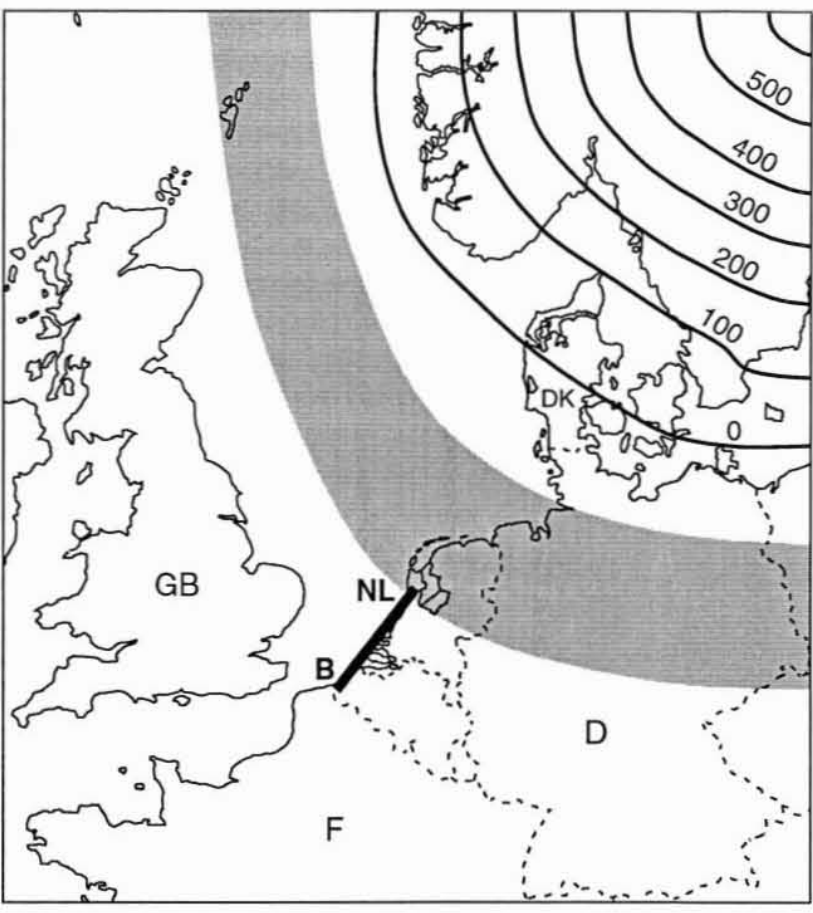

Figure 2 The location of the coastal transect studied from Belgium to the western Netherlands, in relation to the assumed position of the glacial forebulge (shaded area) and the contours in metres of total absolute uplift in Scandinavia (Mörner, 1979)

growth and decay of large ice sheets during the Quaternary glacial-interglacial cycles. The term 'tectonic movements' is used here in a general sense for all long-term $\left(10^{5}-10^{6} \mathrm{yr}\right.$ or longer) movements, which are considered linear at the time-scale under study (roughly the last $125 \mathrm{kyr}$ ). There are actually various processes responsible for these long-term vertical land movements (Kooi et al., 1998): compaction of sediments by burial, long-term (sediment-)isostasy, related to loading by overlying sediments, and tectonics (in the strict sense), primarily resulting from plate tectonic forces and mantle processes. It is difficult, if not impossible, to distinguish among these different processes judging by their end-result-the long-term vertical land-movements-which are therefore here simply called 'tectonic'.

The objective of this paper is threefold. Firstly, we will quantify the observed Holocene differential vertical land movement between Belgium and the western Netherlands and separate the tectonic from the isostatic component. Secondly, we will compare these results, based on geological observational data, with the predictions of isostatic crustal movements from isostatic rebound models. Thirdly, we will present a preliminary evaluation of relative crustal movements between Belgium and the Dutch sector of the southern North Sea by comparing the sea-level curve of Jelgersma (1979) with isostatic rebound model predictions.

\section{Methods}

We use the difference in altitude between sea-level data from Belgium and The Netherlands from the last interglacial (Eemian) sea-level highstand as a measure of the Late Quaternary long-term tectonic movement between both regions. The difference between the Holocene sea-level records for both countries contains this tectonic component 
and a post-glacial isostatic component. We then compare these observational data with the results of geophysical isostatic models as a means to determine possible uncertainties and error margins involved with the data and their interpretation. Although it is not the main purpose of this paper, this comparison will also test how strongly the model predictions of post-glacial differential isostatic land movement in Belgium and The Netherlands depend on the earth model parameters within the range that has been determined from Scandinavian sea-level data. As a linear time-scale is highly preferable in discussions of rates of crustal movement and sea-level rise, all ages are given in calibrated radiocarbon years BP.

\section{Sea-level data}

Sea-level reconstruction in Belgium and The Netherlands is based mainly on radiocarbon ages of samples from the peat bed at the base of the Holocene coastal deposits. This 'basal peat' formed as a result of the sea-level induced rise of the groundwater in the coastal area, and rests on Pleistocene sands or Tertiary sediments. Compaction of these underlying deposits on the time-scale of the Holocene is considered negligible. Dates of the start of basal peat growth yield an upper limit for mean sea-level (MSL), because basal peat growth in a humid climate does not take place below MSL (Jelgersma, 1961). Lower limits for mean high water (MHW) or mean high water spring-tide levels can often be ascertained by dating the transgressive overlaps at the non-eroded top of the basal peat (Denys, 1993). If the basal peat layer is thin, errors in determining the original altitude of the sample owing to compaction of the underlying peat will remain small, and the indicative range can be established by palaeoecological methods such as diatom or pollen analysis. In the most recent sea-level studies based on basal peat data, extreme limits for MSL and/or other tidal levels are derived by careful and integrated analysis of the indicative meaning of the index points, and presented in the form of an error band (Van de Plassche and Roep, 1989; Denys and Baeteman, 1995). An alternative to the basal peat approach is the use of sedimentological evidence from coastal barrier deposits to reconstruct the evolution of palaeotidal levels (Roep and Beets, 1988).

\section{Holocene sea-level data from Belgium}

The MSL error band derived by Denys and Baeteman (1995) is used in this study as representative for the Holocene MSL rise in the Belgian coastal plain. Thıs error band (Fig. 3) extends back in time to $9300 \mathrm{cal}$. yr BP and is based on 40 radiocarbon dates from a compaci study area (approximately $30 \mathrm{~km}$ by $15 \mathrm{~km})$. The data distribution within the study area is shown in Fig. 4. All except two of the dated samples were taken from the basal peat layer. The top of the basal peat was sampled at 19 locations, whereas in the remaining cases the base of the basal peat was used for dating. In two cases, where the basal peat was very thin $(7 \mathrm{~cm}$ and $10 \mathrm{~cm})$, the sample comprised the whole thickness of the basal peat. On the basis of all the data available, the evolution of the local mean high water spring-tide level was reconstructed, with dates from the base of the basal peat used to derive an upper limit of MSL. This interpretation was supported by palaeoecological analyses (pollen, diatoms, plant macrofossils), which were

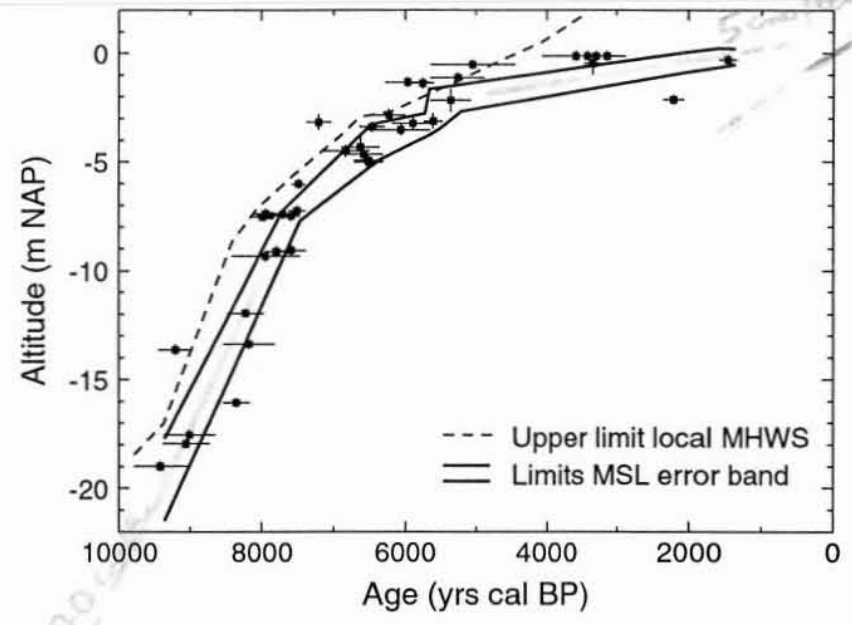

Figure 3 Time-depth distribution of sea-level index points from the Belgian coastal plain, with the upper limit for the highest mean high water spring-tide level and the MSL error band inferred by Denys and Baeteman (1995). The altitude is in metres NAP (Normal Amsterdam Peil or Dutch Ordnance Level, which is approximately $0.1 \mathrm{~m}$ above present-day MSL)

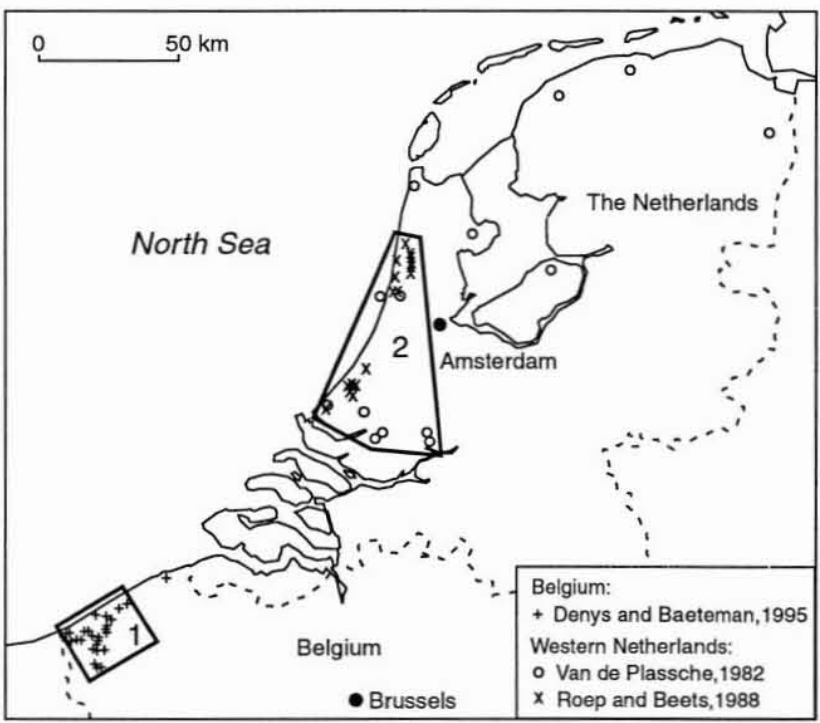

Figure 4 Geographical distribution of the data used for the reconstruction of the Holocene sea-level rise in Belgium and The Netherlands by Denys and Baeteman (1995), Van de Plassche (1982) and Roep and Beets (1988). Each symbol represents a study site that may contain several sea-level index points

useful in determining the conditions of peat growth, the indicative meaning of the samples, and/or the nun-erosive nature of the transition from basal peat to overlying clastic sediments.

The dates for the beginning and end of peat growth were interpreted in a regionally and temporally integrated manner. Dates from the same borehole and dates from different boreholes were checked against each other for consistency. This process was helped by a sound palaeogeographical knowledge of the Holocene evolution of the coastal area (see e.g. Baeteman, 1981; Baeteman and Van Strijdonck; 1989). This allowed rejection of six dates from the analysis and the sea-level reconstruction.

According tc Denys and Baeteman (1995), actual MSL positions rarely can be estimated with a precision exceeding ca. $1 \mathrm{~m}$. This is reflected in the width of their MSL envelope, 
which is between 1 and $1.5 \mathrm{~m}$ wide for the period since ca. 5000 cal. yr BP, but widens considerably prior to that date (to $2.5 \mathrm{~m}$ at 8000 cal. $\mathrm{yr} \mathrm{BP}$ and $3.5 \mathrm{~m}$ at 9000 cal. yr BP). Contributing errors include: (i) determination of sample altitude (mostly $\pm 0.1 \mathrm{~m}$, in a few cases $0.2 \mathrm{~m}$ or $0.3 \mathrm{~m})$; (ii) determination of indicative meaning $( \pm 0.1 \mathrm{~m})$; (iii) estimation of compaction of the underlying peat in the case of dates from the top of the basal peat (the basal peat mostly was less than $0.4 \mathrm{~m}$ thick; a compaction factor of $50 \%$ was assumed, which may be an underestimation in a number of cases, but may be an overestimation in the case of fen-wood peats (Behre and Streif, 1980; Menke, 1988)) and (iv) dating uncertainties, especially for the period prior to $7500 \mathrm{cal}$. yr $\mathrm{BP}$ and because $2 \sigma$ age ranges were used for radiocarbon age calibration.

\section{Holocene sea-level data from the western Netherlands}

The most recent reconstructions of the Holocene sea-level rise in the western Netherlands are by Van de Plassche (1982), who used predominantly basal peat data (Fig. 5), and Roep and Beets (1988), who based their reconstruction of palaeotidal levels on detailed sedimentological observations of beach barrier deposits (Fig. 6). The geographical distribution of the sea-level index points used in both studies is shown in Fig. 4. The two independently established sea-level curves were compared and their accuracy discussed by Van de Plassche and Roep (1989).

Van de Plassche (1982) provided a detailed discussion of the data and methods used in previous sea-level studies in The Netherlands. This comprised a comprehensive evaluation of existing sea-level index points from the Dutch coastal zone. In addition, about 60 new basal peat dates were collected from the western Netherlands coastal region. Van de Plassche (1982) identified various factors that may influence the time-depth position of sea-level index points (e.g. tidal damping within tidal inlets and basins, the influence of groundwater and river gradient effects on the time-depth position of initial basal peat growth, and contamination of radiocarbon samples by younger or older material). On the basis of this evaluation, a careful selection of the available sea-level index points could be made, of which 35 were used for the reconstruction of relative MSL rise during the period 7000-2750 cal. yr BP (Fig. 5). Only a few of the index points used came from sites other than the western Netherlands coastal area, and their time-depth position does not differ significantly from those of the western Netherlands. Van de Plassche (1982) concluded that during the past $6000 \mathrm{yr}$, the northern Netherlands did not experience notable crustal subsidence with respect to the western Netherlands. On this basis, his sealevel curve was considered to be representative for sea-level rise in both the western and the northern Netherlands coastal areas.

Roep and Beets (1988) based their reconstruction of palaeotidal levels during the past $6500 \mathrm{yr}$ (Fig. 6) on sedimentological features identified in coastal barrier sequences exposed in open pits at 19 sites along the western Netherlands coast. Radiocarbon dating was mostly performed on paired shells from marine or brackish pelecypods contained in the sedimentary sequence. In a few cases, other dating methods were used (historical data, charcoal, peat and pollen zonation). The MHW level was inferred from the deepest occurrence of dry aeolian scour, and from the highest levels of marine burrows and small-scale cross-lamination. Mean low water (MLW) levels were estimated based on the level of thickest shell beds, the vertical range of structureless sand, bubble sand and/or low-angle bars, and the occurrence of centimetre-thick clay intercalations. The MSL is drawn halfway between the mean high and mean low water estimates, thus actually representing half tide level. Because of tidal wave asymmetry, this may be $0.15 \mathrm{~m}$ above or below MSL (Van de Plassche and Roep, 1989). Roep and Beets (1982) estimated the total error margins on their palaeotidal-level curves to be a few decimetres for MHW level and MSL, and in the order of $0.5 \mathrm{~m}$ for the MLW level.

Van de Plassche and Roep (1989) compared and evaluated the sea-level results of Van de Plassche (1982) and Roep and Beets (1988). They also derived a new error band for

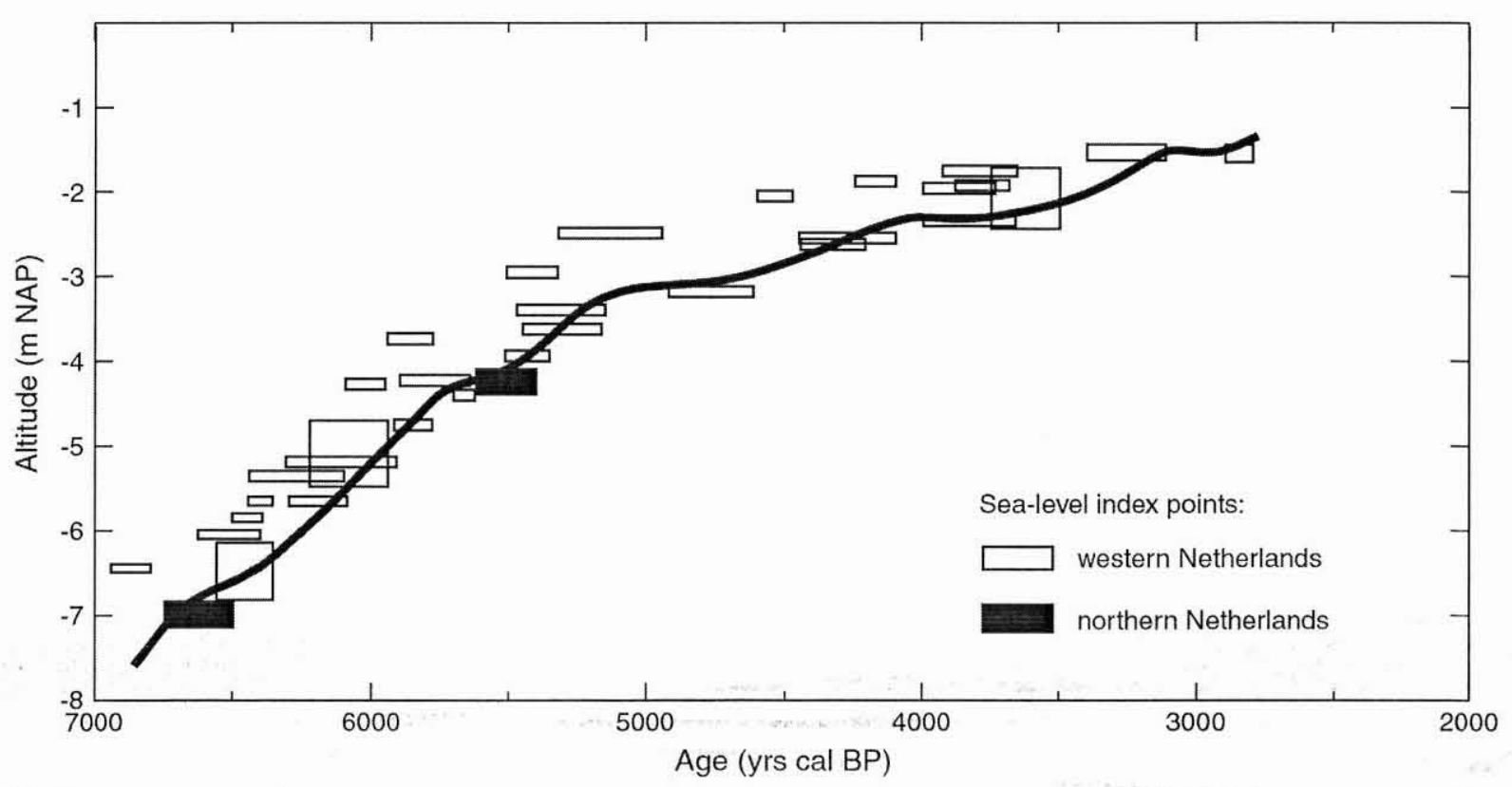

Figure 5 Curve of relative MSL rise in the western and northern Netherlands according to Van de Plassche (1982), with the sea-level index points used for its construction. Shown here is the calibrated version of this curve (Van de Plassche's fig. 69) 


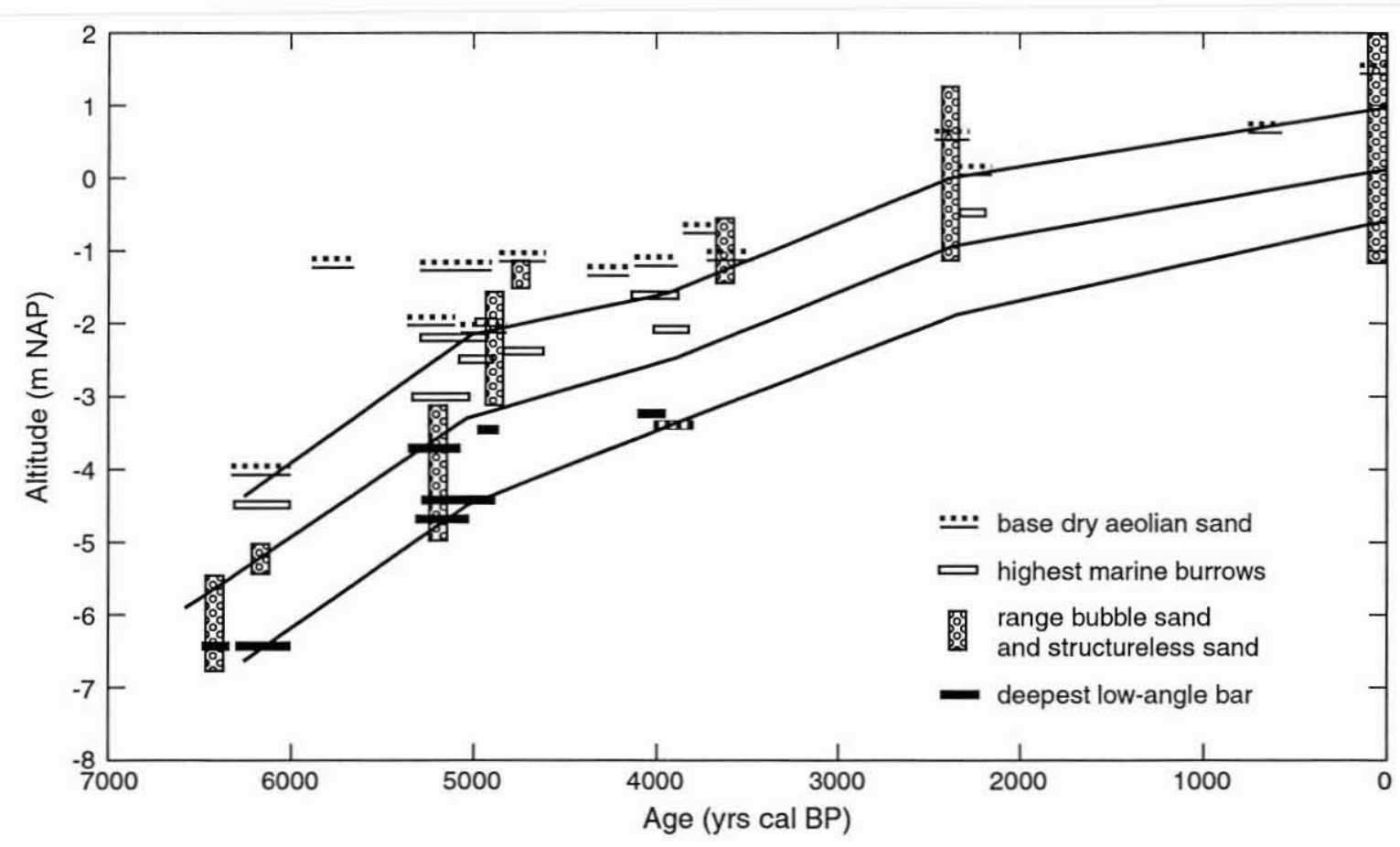

Figure 6 Trend curves for MHW, MSL and MLW for the western Netherlands inferred from sedimentological palaeotide level indicators in coastal barrier deposits (Roep and Beets, 1988)

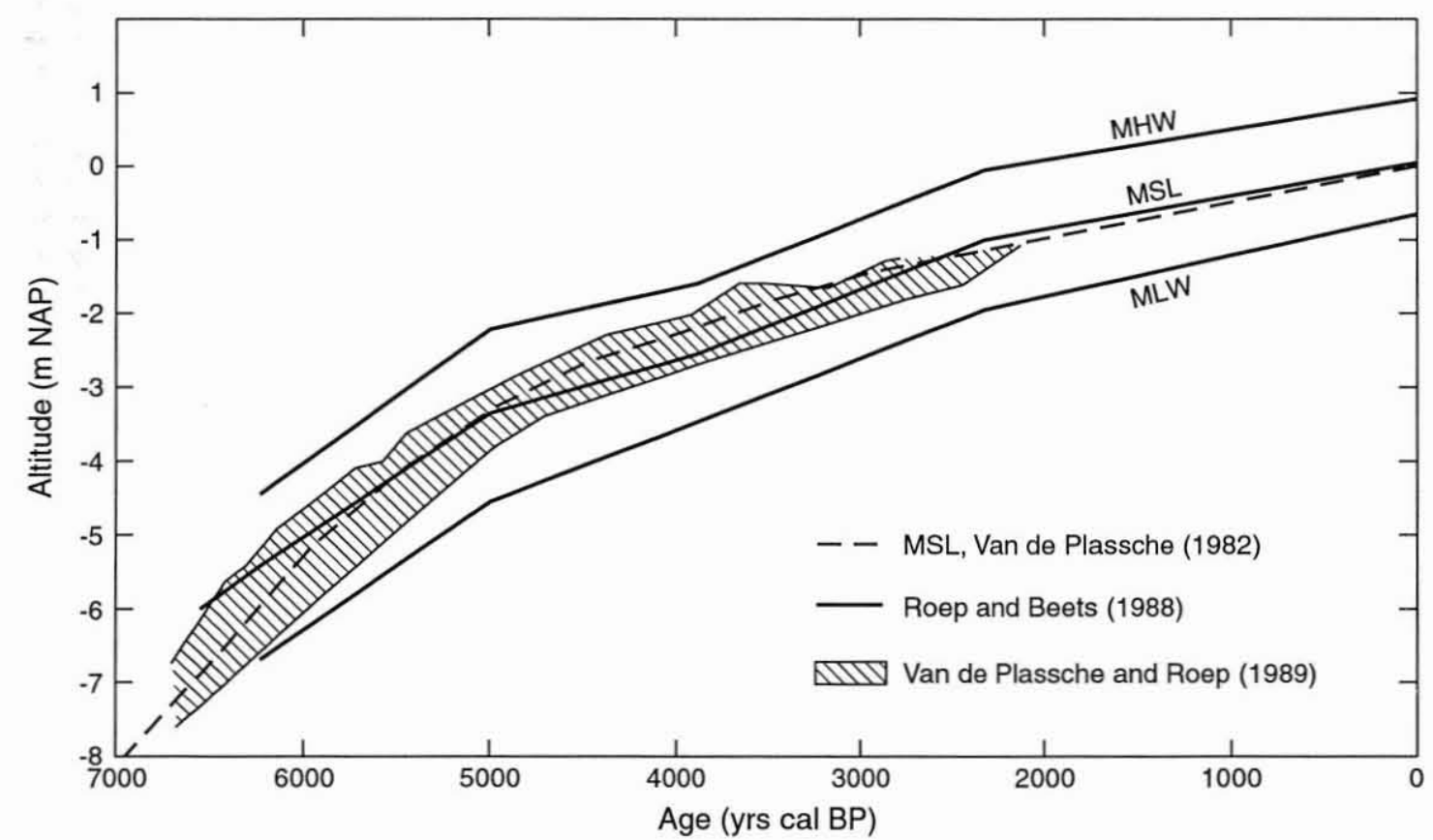

Figure 7 Comparison of the MSL curve of Van de Plassche (1982), the palaeotidal levels reconstructed by Roep and Beets (1988), and the new MSL error band established by Van de Plassche and Roep (1989). The MSL curve of Van de Plassche (1982) shown here is the smoothed version of the slightly fluctuating curve in Fig. 5

the upper and lower limits of MSL from available basal peat data and other sea-level related indicators (e.g. archaeological occupation levels, height of surfaces of saltmarsh deposits and tidal creek levees) (Fig. 7). This error band established MSL rise in the western Netherlands with a minimum accuracy ranging from $\pm 0.75 \mathrm{~m}$ to $\pm 0.30 \mathrm{~m}$ (Van. de Plassche and Roep, 1989). This new MSL error band falls completely within the MHW to MLW level range as reconstructed by Roep and Beets (1988), and also encompasses their MSL curve. The good agreement between these two interpretations, which are based on independent data sets, provides strong support for the underlying assumptions and estimates that were made in deriving them. The general trend of the new MSL error band, in particular of the older part, is somewhat steeper than the MSL curve derived by Roep and Beets (1988). Because this (small) difference remains to be explained, we choose to use the MHW and MLW level estimates of Roep and Beets (1983) as more conservative limits for the MSL error band representative for the western Netherlands. 
Holocene sea-level data from the Dutch sector of the North Sea

The only available sea-level curve for the Dutch sector of the North Sea was established by Jelgersma (1979) (Fig. 8). The curve was constructed on the basis of dates from basal peat from the North Sea floor, which were connected to a sea-level curve for the mainland of The Netherlands that was derived from basal peat samples mainly originating from the coastal area of the western Netherlands (Jelgersma, 1979, fig. $\mathrm{V}$-13). This 'land-based' curve is reasonably well constrained by index points down to approximately $15 \mathrm{~m}$ in depth, or ca. 8000 cal. yr BP (not shown in Fig. 8). Most of these index points have also been used by Van de Plassche (1982) in the construction of his sea-level curve (see above), which is actually very similar to the 'land-based' curve of Jelgersma (1979) (Fig. 8).

As can be seen in Fig. 8, the part of the North Sea curve deeper than ca. $20 \mathrm{~m}$ is only loosely constrained by a small number of sea-level index points, which have large age and depth errors (Table 1). In addition, the time-depth position of four index points was established on the basis of palynologically derived age estimates of peat samples dredged from the sea floor and not absolute dating evidence Jelgersma, 1961), which introduces large age and depth errors. The data cover a very large geographical area, containing the whole of the Dutch sector of the North Sea with some data points even coming from adjacent regions (two from the German sector and one from the Dover Strait) (Fig. 9). Furthermore, some doubt can be raised on the position of the sea-level curve with respect to index point 3 . This is a date from the non-eroded top of the basal peat overlain by marine sediments, and was judged by Ludwig et al. (1981) to be a good indicator of the onset of marine influence at that site. Thus, one would expect the sea-level curve passing through or at least much closer to this index point.

In view of the above-mentioned problems, and in the absence of more and better data, an assessment of the North Sea curve of Jelgersma (1979) is virtually impossible to make. However, we will try to give a preliminary analysis below, combining the sea-level curve, the index points on which it is based, and geophysical model predictions of the subsidence at different sites in the North Sea relative to the Belgian coastal area.

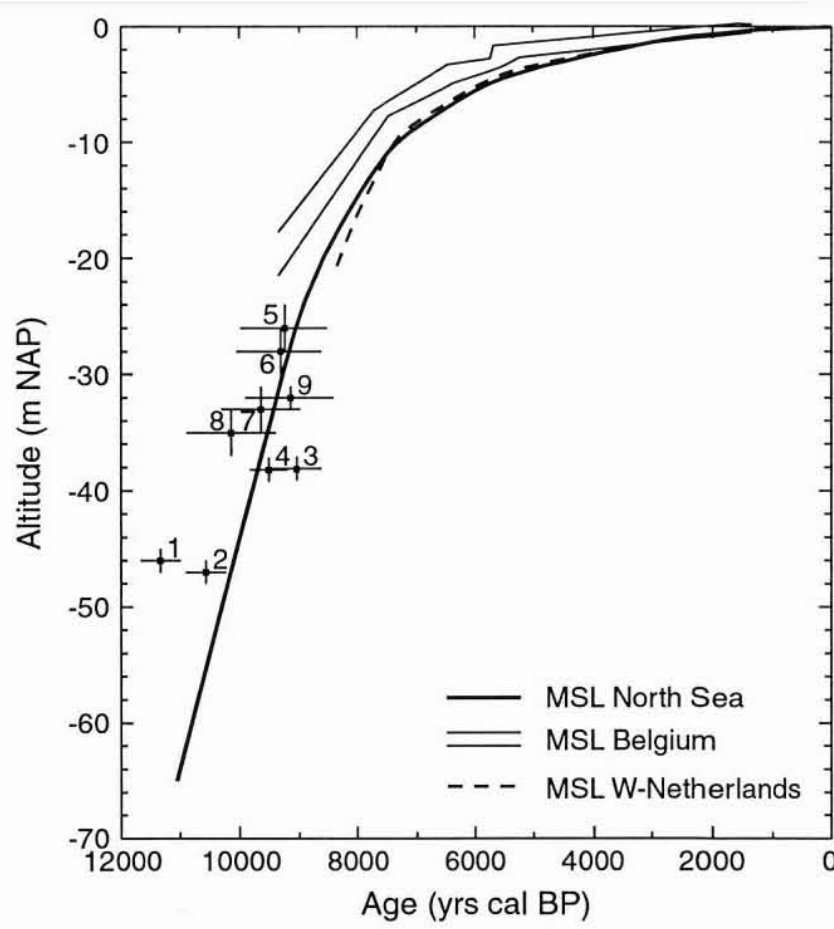

Figure 8 Sea-level curve for the Dutch sector of the North Sea (after Jelgersma, 1979; calibrated), and sea-level index points on which it is based. For comparison, the MSL error band for the Belgian coastal area of Denys and Baeteman (1995) and the MSL curve of Van de Plassche (1982) for the western Netherlands are also shown

\section{Eemian sea-level data}

Eemian sea-level indicators for Belgium and The Netherlands consist mainly of palynologically dated organic layers within and on top of a transgressive sequence of clastic coastal tidal deposits. In the Belgian coastal plain, these deposits occur at a very shallow depth and have been studied extensively in boreholes and in open pits (e.g. Paepe et al., 1972; Vandenberghe et al., 1974; Mostaert and De Moor, 1984). In this study, the Eemian sea-level curve of Mostaert and De Moor (1989) is used for the Belgian coastal plain. In The Netherlands, Eemian marine deposits are found deeper than in Belgium (Bosch et al., 2000). Their highest occurrence is in the type area near Amersfoort (Fig. 1) (Zagwijn, 1983; Cleveringa et al., 2000). Zagwijn (1983) established an Eemian

Table 1 Sea-level index points from the North Sea, based on dates from the basal peat, that were used in the construction of the sea-level curve for the Dutch sector of the North Sea (Jelgersma, 1979)

\begin{tabular}{|c|c|c|c|c|c|c|}
\hline Index point & $\begin{array}{l}\text { Laboratory } \\
\text { number }\end{array}$ & Radiocarbon age & $\begin{array}{c}\text { Calibrated age } \\
\text { ( } 2 \sigma \text { range })\end{array}$ & $\begin{array}{c}\text { Depth } \\
\text { below } \\
\text { MSL (m) }\end{array}$ & $\begin{array}{c}\text { Depth } \\
\operatorname{error}^{\mathrm{c}}(\mathrm{m})\end{array}$ & Reference \\
\hline 1 & GrN5758 & $9935 \pm 55$ & $11667-10993$ & -46 & 1 & Jelgersma et al., 1979 \\
\hline 2 & GrN5759 & $9445 \pm 80$ & $10894-10214$ & -47 & 1 & Jelgersma et al., 1979 \\
\hline 3 & Hv7095 & $8190 \pm 140$ & $9450-8618$ & -38.09 & 1 & Behre et al., 1979; Ludwig et al., 1981 \\
\hline 4 & Hv7094 & $8485 \pm 125$ & $9822-9210$ & -38.19 & 1 & Behre et al., 1979; Ludwig et al., 1981 \\
\hline 5 & Pollen $\mathrm{A}^{\mathrm{a}}$ & $8400 \pm 300^{b}$ & $10000-8500$ & -26 & 2 & Jelgersma, 1961 \\
\hline 6 & Pollen $\mathrm{D}^{\mathrm{a}}$ & $8500 \pm 300^{b}$ & $10000-8600$ & -28 & 2 & Jelgersma, 1961 \\
\hline 7 & Pollen $\mathrm{C}^{\mathrm{a}}$ & $8700 \pm 300^{b}$ & $10300-9000$ & -33 & 2 & Jelgersma, 1961 \\
\hline$\cdots+2$ & Pollen Ba & $9000 \pm 300^{b}$ & $10900-9400$ & -35 & 2 & Jelgersma, 1961 \\
\hline 9 & GiF1614 & $8250 \pm 300$ & $9887-8405$ & -32 & 1 & Morzadec-Kerfourn and Delibrias, 1972 \\
\hline
\end{tabular}

\footnotetext{
a Palynologically-dated samples.

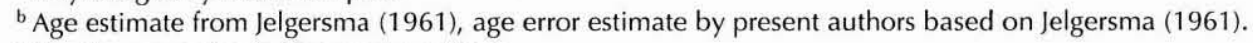

${ }^{c}$ Depth error estimate by present authors.
} 


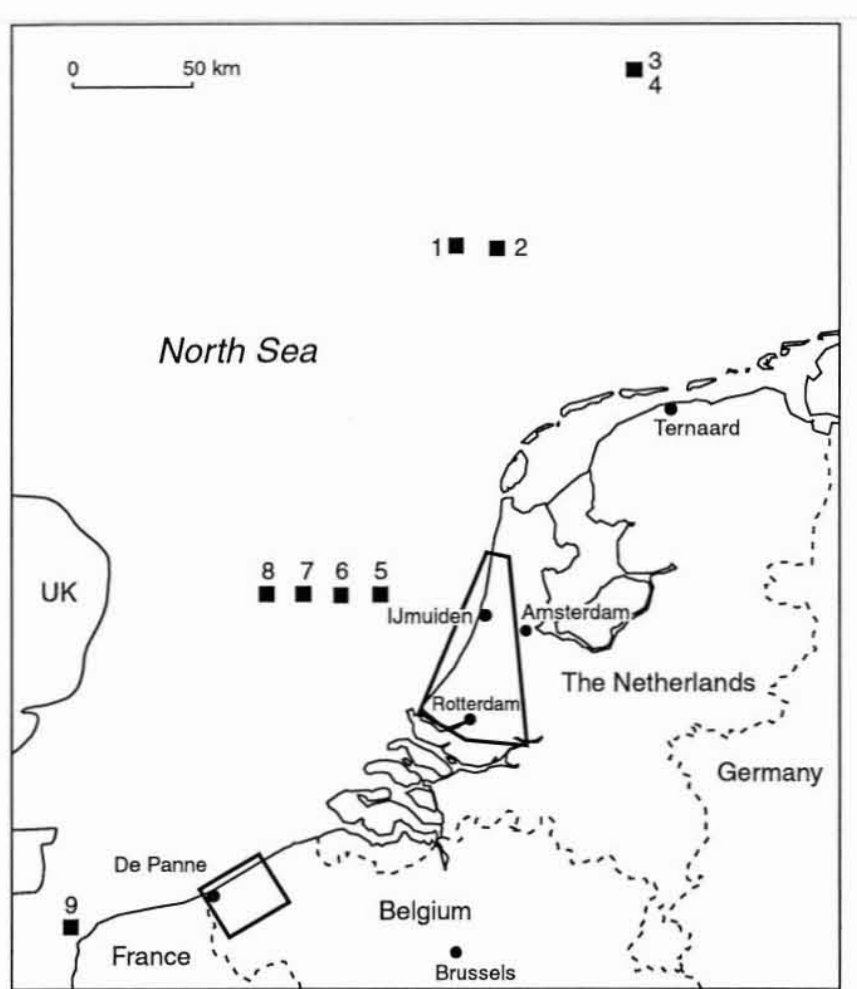

Figure 9 Geographical distribution of the sea-level index points, mainly from the Dutch sector of the North Sea, used in the construction of the North Sea curve of Jelgersma (1979), together with the discussed study areas in Belgium and the western Netherlands

sea-level curve that will be used here for The Netherlands. The Eemian sea-level highstand is at about $1 \mathrm{~m}$ to $2 \mathrm{~m}$ below present-day MSL in Belgium and at $9 \mathrm{~m}$ to $10 \mathrm{~m}$ below MSL in The Netherlands. It is possible that the timing of this highstand was not completely synchronous in Belgium and The Netherlands. Maximum sea-levels in Belgium seem to have been reached during the period of pollen zone E4b or at the start of E5 (Mostaert and De Moor, 1989), whereas in The Netherlands this happened at the beginning of pollen zone E5 (Zagwijn, 1983) (pollen zonation according to Zagwijn, 1961). However, according to Zagwijn (1996), who correlates the Eemian pollen zonation with a time-scale established on the basis of annually layered sediments reported by Müller (1974), this age difference in the timing of the highstand amounts to $2000 \mathrm{yr}$ or less. This translates to an error of less than $2 \%$ over the time-scale under consideration (125 kyr).

\section{Geophysical modelling methods}

The deglaciation history of the Late Pleistocene ice sheets over Fennoscandia, the British Isles and further afield is partly constrained by geomorphological data such as glacial end moraines and ice-flow indicators. In response to the melting of these ice sheets, isostatic relaxation of Earth's surface occurs at a rate that is governed by mechanical properties of Earth, in particular mantle viscosity and lithospheric thickness. The isostatic relaxation is registered in the geological record by post-glacial sea-level indicators. The wide availability of such data in Fennoscandia and the British Isles, combined with rigorous modelling of sea-level change for a variety of ice and Earth parameters, has resulted in an ice-Earth model combination that is in good agreement with sea-level observations from these regions (Lambeck et al., 1998).

The isostatic relaxation of Earth in response to the melting of the ice sheet depends strongly on the position of a site in relation to the ice sheet and on its size. Belgium and The Netherlands are sufficiently close to the Fennoscandian ice-sheet that there are significant differences in sea-level predictions between the two countries, yet the glacio-isostatic effects from all the other ice sheets are virtually identical in the two countries because of the great distance to those ice sheets, or in the case of the British ice sheet, the small volume of ice that this ice sheet released on melting.

The earth model used to predict sea-level change has an elastic lithosphere of thickness $H_{1}$, and a Maxwell viscoelastic mantle with a uniform upper mantle (to depth $670 \mathrm{~km})$ viscosity $\left(\eta_{\mathrm{um}}\right)$ and a lower mantle of viscosity $\left(\eta_{\mathrm{Im}}\right)$. The parameters that best fit the sea-level data for Fennoscandia have the values $\left(H_{1}=75 \mathrm{~km}, \eta_{\mathrm{um}}=3.6 \times 10^{20}\right.$ Pa s, $\eta_{\mathrm{Im}}=8 \times 10^{21} \mathrm{~Pa} \mathrm{~s}$ ) (Lambeck et al., 1998). Models that give acceptable fits to the Fennoscandian data are in the range $\left(60<H_{1}<80,3 \times 10^{20}<\eta_{\text {um }}<5 \times 10^{20}, 5 \times 10^{21}<\right.$ $\left.\eta_{\mathrm{lm}}<3 \times 10^{22}\right)$. Therefore to determine the range of sea-level predictions for plausible earth models, we calculate sea-level using the best-fit earth model and combinations of the most extreme values of these parameters, resulting in nine different models. The models are named using three numbers: the lithospheric thickness in kilometres and the upper and lower mantle viscosities in units of $10^{21} \mathrm{~Pa}$ s. For example the best fitting model is labelled $(75,0.36,8)$. For reasons of clarity, we will use only this best-fit model and the two models that yield the largest $(80,0.5,30)$ and the smallest $(80,0.3,5)$ difference in sea-level predictions across the region under study. These two 'extreme' models thus delimit an envelope that comprises the sea-level predictions of all nine calculated models.

\section{Results}

\section{Background tectonic movements}

The long-term tectonic movement since the Eemian interglacial (125 kyr BP) has been derived from Eemian sea-level data in Belgium and in The Netherlands. The level of the Eemian sea-level highstand is $8 \mathrm{~m}$ lower in The Netherlands than in Belgium (see above). This yields a tectonic subsidence of $0.06 \mathrm{~m} \mathrm{kyr}^{-1}$. However, on this relatively long time-scale, the possibility of differential tectonic movements within the study area should not be ignored. If this were the case, then the Dutch coastal area, where the Holocene sea-level data come from, might be subject to a different rate of tectonic subsidence than the Amersfoort region, where the Eemian highstand sea-level data originate.

During the past decade, it has been demonstrated that tectonic movements on a small spatial scale $(<50 \mathrm{~km})$ do take place in The Netherlands (Lorenz et al., 1991; Kooi et al., 1998): For example, Kooi et al. (1998) used a digital data base of Cenozoic chronostratigraphical marke: horizons to analyse long-term vertical land movement rates using the backstripping technique. Their results show that, averaged over the duration of the Quaternary (2.5 Ma), the long-term differential subsidence of the western Netherlands coastal area 
relative to the Amersfoort region varies between 0.02 and $0.10 \mathrm{~m} \mathrm{kyr}^{-1}$, depending on the precise location within the coastal area (see fig. 4 in Kooi et al., 1998). Therefore, the $0.06 \mathrm{~m} \mathrm{kyr}^{-1}$ subsidence rate derived above, based on the highest Eemian sea-level data from The Netherlands, must be considered as a lower limit. Correcting the Dutch Eemian sealevel data for the higher subsidence in the coastal region yields a maximum tectonic subsidence of the western Netherlands coastal area with respect to Belgium of $0.16 \mathrm{~m} \mathrm{kyr}^{-1}$. This corresponds to a difference in altitude of the Eemian highstand of about $20 \mathrm{~m}$. This value is used in the following analysis as the upper limit for the long-term tectonic subsidence of The Netherlands relative to Belgium.

\section{Isostatic versus tectonic movements}

Figure 10 shows that the difference in altitude between the Holocene MSL error bands of Belgium and the western Netherlands increases with increasing age. This is made clearer by plotting the altitude of the MSL error band of The Netherlands relative to that derived from Belgium (Fig. 11). Figure 11 indicates that the rate of subsidence of the western Netherlands coastal area relative to the Belgian coastal plain decays gradually over the past $7500 \mathrm{yr}$, from an average of ca. $0.66 \mathrm{~m} \mathrm{kyr}^{-1}$ for the period $7500-5000 \mathrm{cal}$. yr BP to an average value of no more than $0.25 \mathrm{~m} \mathrm{kyr}^{-1}$ for the period since $5000 \mathrm{cal}$. yr BP.

The total relative crustal movements prior to $5000 \mathrm{cal}$. $\mathrm{yr} B P$ are 4 to 11 times faster than the differential tectonic subsidence of The Netherlands since the Eemian (0.06 to $0.16 \mathrm{~m} \mathrm{kyr}^{-1}$ ) (Fig. 11). Therefore, they cannot have operated at the same rate during the pre-Holocene (Weichselian) period. This implies that the total relative crustal movement averaged over the duration of the Weichselian must have been much slower, or even the inverse of the movement observed during the Holocene (i.e. Belgium may have been subsiding relative to The Netherlands). We therefore argue that the Holocene data contain an important and slowly decaying isostatic component in addition to the constant tectonic subsidence component of

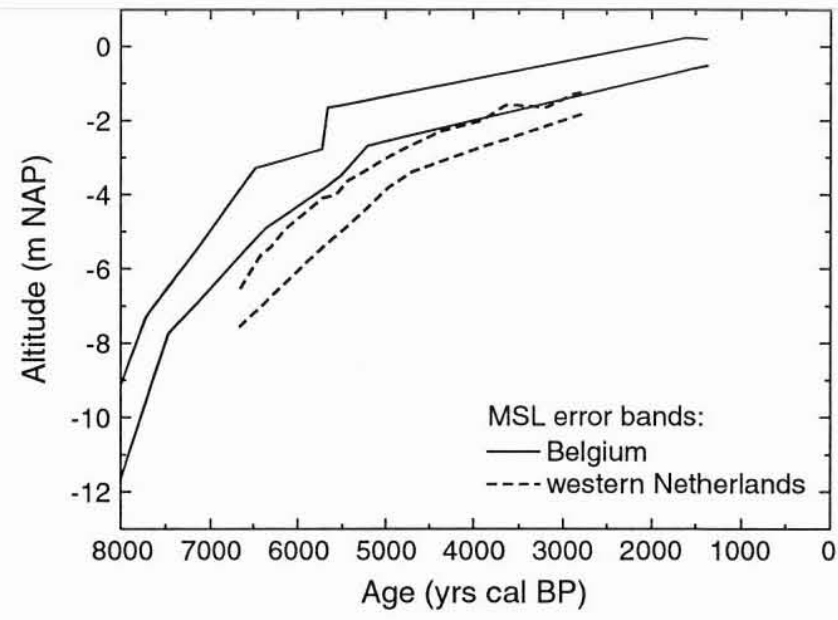

Figure 10 Comparison of the Holocene sea-level error bands for Belgium and the western Netherlands used in this study

0.06 to $0.16 \mathrm{~m} \mathrm{kyr}^{-1}$. This isostatic component is the record of the last phase of the glacio-isostatic subsidence of The Netherlands relative to Belgium, which is associated with the Fennoscandian glacial rebound. This may be the result of the collapse of a glacial forebulge under The Netherlands and the Dutch (and German) sectors of the North Sea. There is probably also a hydroisostatic component involved, resulting from water loading of the North Sea Basin owing to the post-glacial eustatic sea-level rise.

\section{Comparison with geophysical modelling results}

Figure 12 is a repeat of Fig. 11, but now with predictions from the best-fit and the 'extreme' models added. In general, the model predictions of the difference in Holocene sea-level rise between Belgium and the western Netherlands fit the observations quite well, but tend to underestimate slightly the total differential movement between both regions (Fig. 12A).

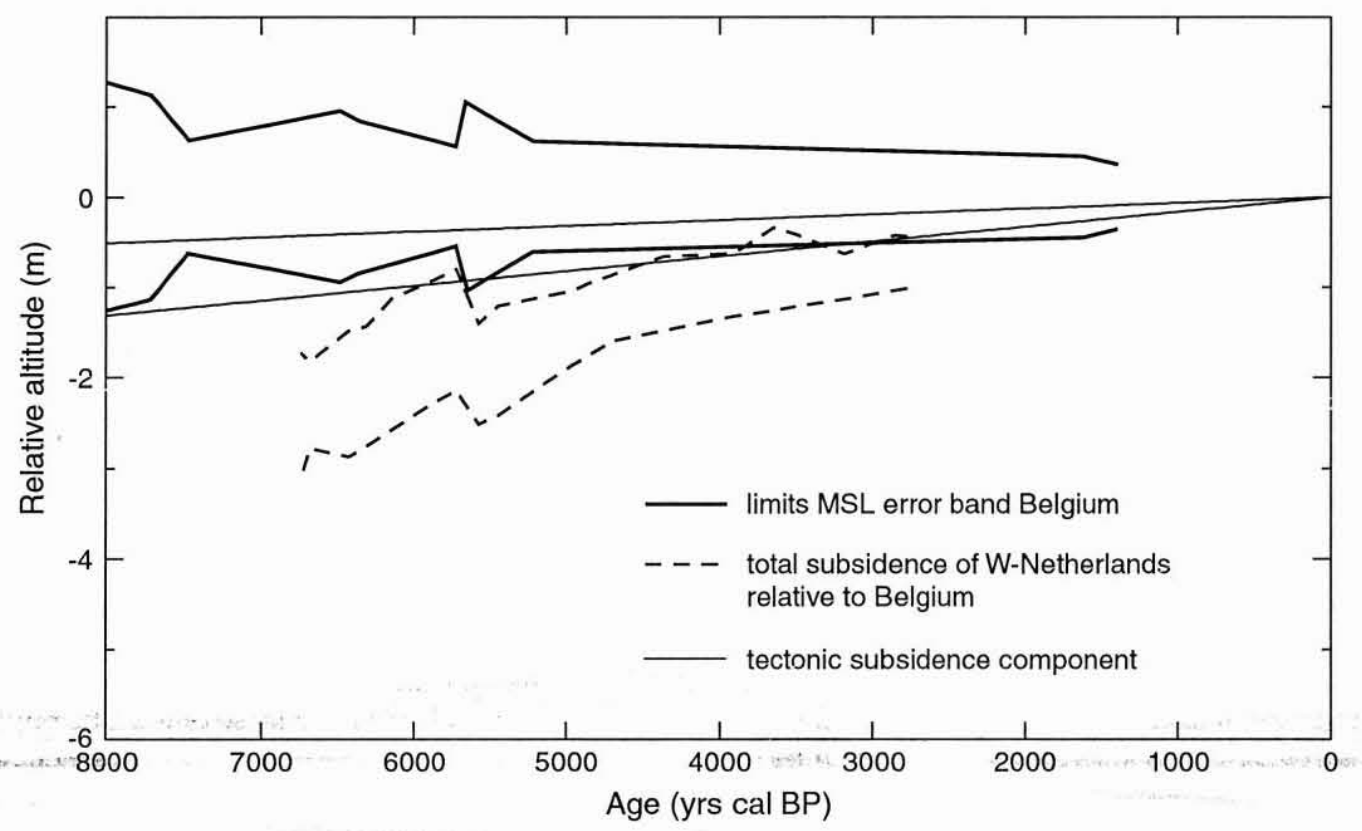

Figure 11 Holocene MSL in the western Netherlands plotted relative to MSL in Belgium, together with the error band for long-term tectonic movement since the Eemian ('tectonic subsidence component') 

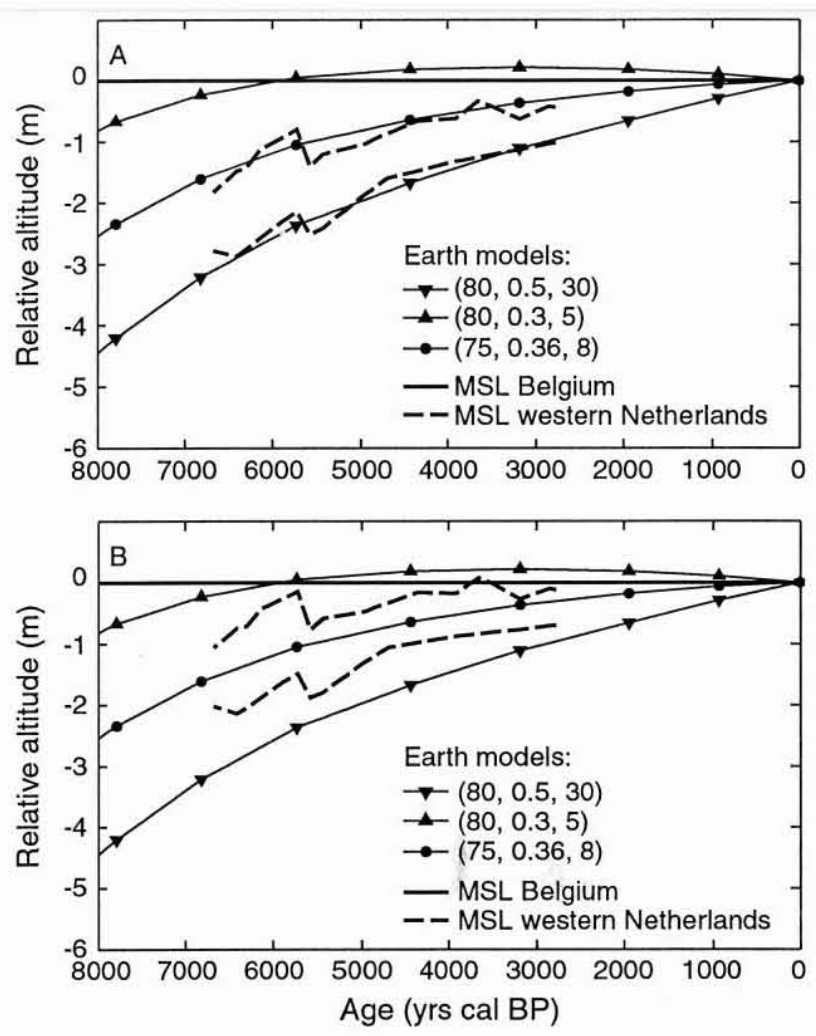

Figure 12 Differential crustal movements between Belgium and the western Netherlands compared with the predictions of the isostatic rebound models of Lambeck et al. (1998) based on various sets of earth parameters. The predictions are calculated for the sites of De Panne in Belgium and IJmuiden in the western Netherlands (Fig. 1). For reasons of clarity, the limits for the MSL error band for Belgium have been omitted from this diagram. (A) Total differential movement. (B) Isostatic component only (long-term differential tectonic movement between both regions, here taken as the average of 0.06 and $0.16 \mathrm{~m} \mathrm{kyr}^{-1}$, subtracted from the total differential movement)
The fit of the model to the observations improves when the tectonic subsidence component is removed (Fig. 12B). This was to be expected because the isostatic rebound models do not take into account tectonic movements (Lambeck, 1997; Lambeck et al., 1998). Figure 12B now shows a good agreement between empirical observation and the best-fit earth model $(75,0.36,8)$ : its predictions are near the centre of the error band for the isostatic subsidence of the western Netherlands relative to Belgium. The predictions of the two extreme models are somewhat outside this error band, with model $(80,0.5,30)$ overestimating the differential isostatic movement by slightly more than $1 \mathrm{~m}$ at $6000 \mathrm{cal}$. yr BP, and model $(80,0.3,5)$ underestimating it by approximately the same amount.

\section{Data from the Dutch North Sea sector: preliminary assessment}

Figure 13 shows the depth of the sea-level curve for the Dutch sector of the North Sea by Jelgersma (1979), plotted relative to the MSL error band for the Belgian coastal area. This could be done only for the past $9300 \mathrm{cal}$. yr BP, which is the age range of the Belgian MSL error band. Also plotted is the relative altitude of a number of the index points used by Jelgersma (1979), and predictions from isostatic rebound modelling of crustal movements relative to Belgium for various sites in the North Sea and in the coastal area of The Netherlands. From the nine available index points, only those from the Dutch and adjacent German sector of the North Sea will be used in this analysis (index point 9 is omitted). Only the relative altitude of index points 3, 5 and 6 can be represented within the age range of the Belgian MSL error band. For index points 4 and 7 a linear extrapolation of this band over less than $300 \mathrm{yr}$ was used.

As can be seen in Fig. 13, the geophysical model predicts spatially highly variable isostatic movements relative to

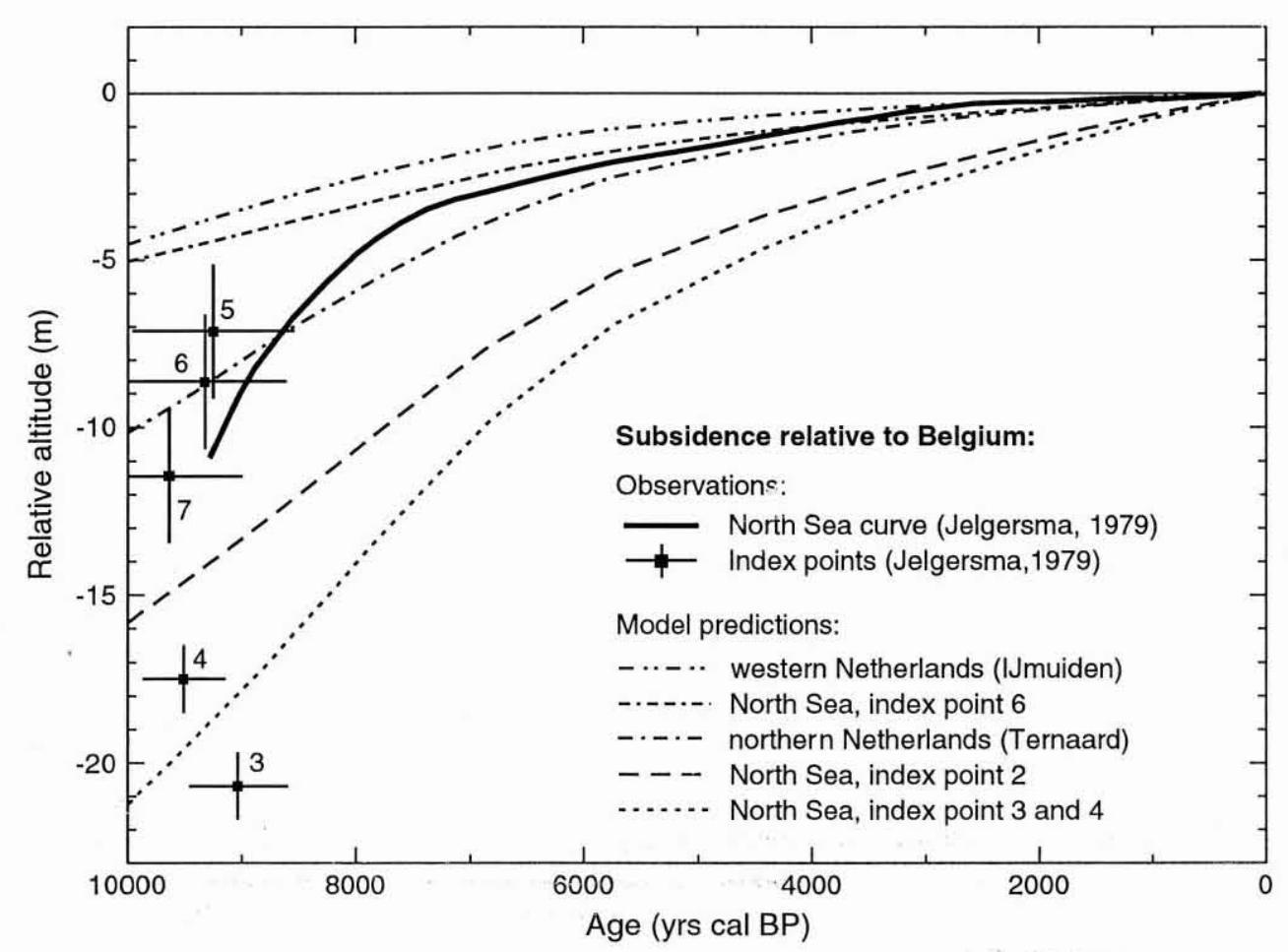

Figure 13 Sea-level observations and geophysical model predictions of isostatic crustal movement for various locations in the southern North Sea and on the Dutch coast, all plotted relative to MSL in Belgium. The model predictions are based on the best-fit earth model $(75,0.36,8)$ 
Belgium for various sites in the North Sea and along the Dutch coast. The predictions are in good agreement for data points 3 and 4 , but less so for 5,6 and 7 , where the model seems to underestimate the amount of relative subsidence. However, the age and depth errors for these latter three index points are very large (see above), and perhaps may even be underestimated here. It is possible that the dredged peat samples contain material reworked and transported from a higher position (Jelgersma, 1961). Also, these sites may have undergone some additional tectonic subsidence, which is not taken into account by the isostatic rebound models and could make up for 1 to $2 \mathrm{~m}$ of the difference in altitude.

The amount of glacio-hydroisostatic subsidence relative to Belgium decreases strongly in a southerly direction (Fig. 13). The subsidence predicted for sites 5, 6, 7 and 8 off the coast of the western Netherlands, however, is only slightly larger than for the coastal area itself (IJmuiden). This analysis suggests that the strong north to northeasterly orientated component of the spatially variable crustal movements over the past $10 \mathrm{kyr}$ is related to the subsidence of the peripheral bulge around the zone of Fennoscandian glacio-isostatic rebound, whereas the smaller northwesterly component is the result of the hydroisostatic depression of the North Sea floor owing to increased water load during the post-glacial period. Although the amount of subsidence relative to Belgium differs from site to site (Fig. 13), the pattern is similar for the different sites: a gradual decay of the relative altitude up to the present day, with a weak knickpoint between ca. 7000 and $6000 \mathrm{cal}$. yr BP. This appears to be the general pattern for the isostatic subsidence of the North Sea floor off the Belgian and Dutch coast, measured relative to MSL in Belgium.

The relative altitude plotted for the North Sea curve of Jelgersma (1979) does not follow this pattern (Fig. 13). Prior to ca. 8000 cal. yr BP it is much steeper relative to MSL in Belgium than the general trend predicted by the models. This part of the curve is forced downward to pass through the loose cluster of data points from the North Sea on which it is based. It would suggest a rapid crustal subsidence of the North Sea area relative to Belgium during this period-more rapid than predicted by the isostatic rebound model. The part of the curve since ca. 8000 cal. yr BP is much more horizontal, which would imply a strong decrease of the rate of relative crustal subsidence around ca. $8000 \mathrm{cal}$. yr BP. However, this is not in agreement with the predictions of the isostatic rebound model. This younger part of the curve is based on basal peat dates from the coastal area of the western Netherlands (see above). Therefore this post- 8000 cal. yr BP part of the North Sea curve closely follows the trend predicted for sites in the western Netherlands or off the western Netherlands coast, instead of the trend for the more northerly sites in the North Sea.

In summary, because the North Sea curve of Jelgersma (1979) is based on sea-level index points from regions with significantly different isostatic subsidence histories, it cannot be considered to be representative for any one of these regions. Moreover, the curve overestimates the subsidence rate and the rate of sea-level rise for the period prior to ca. $8000 \mathrm{cal}$. $\mathrm{yr}$ BP, because it tries to connect data points from the North Sea with a low time-depth position that were subject to a large amount of isostatic subsidence with younger and higher index points from the western Netherlands that underwent far less subsidence.

\section{Discussion and conclusions}

The observed and modelled patterns of relative movements between Belgium and the western Netherlands over the past $10 \mathrm{kyr}$ suggest that The Netherlands were situated closer than Belgium to the centre of the zone of peripheral bulge collapse around the Fennoscandian centre of ice loading. Belgium was to the southwest of this zone, on the southern or distal 'slope' of the bulge. Neither the empirical observations nor the model results of the differential crustal movements between Belgium and The Netherlands require the migration of the collapsing peripheral bulge underneath Belgium and The Netherlands.

Holocene sea-level data from the northern part of the Dutch sector of the North Sea show a larger subsidence than those from areas further to the south, such as the western Netherlands. The same is also true for sea-level data from the German part of the North Sea (Ludwig et al., 1981). This suggests that the central part of the peripheral bulge, which is subject to the largest amount of Holocene isostatic subsidence, may be located north of The Netherlands, under the German and northern part of the Dutch sector of the North Sea. If this is the case, then data from the northern Netherlands should plot lower than similarly dated index points from the western Netherlands coastal area. This is in agreement with the model predictions for Ternaard, which indicate a considerable amount of isostatic subsidence of the northern Netherlands coastal area with respect to the western Netherlands (Fig. 13). So far, this hypothesis is not substantiated by the sea-level index points from the northern Netherlands that were evaluated by Van de Plassche (1982). Their time-depth position does not differ significantly from the data from the western Netherlands (Fig. 5). However, because the basal peat data from the northern Netherlands represent only an upper limit for contemporaneous MSL, the possibility of stronger isostatic subsidence in the north cannot be rejected on the basis of the small number of dates available from the northern coastal region. New data, preferably older than 8000 cal. yr BP, should be collected in the northern part of the country to test this hypothesis.

The coastal area of Zeeland in the southwestern Netherlands occupies an intermediate position between Belgium and the western Netherlands (Fig. 1). Holocene sea-level data from this region (Kiden, 1995) yield an upper limit for the total crustal movement (uplift) relative to the western Netherlands of $0.17 \mathrm{~m} \mathrm{kyr}^{-1}$, averaged over the past $8000 \mathrm{cal}$. $\mathrm{yr}$ BP. This figure is somewhat lower than the uplift of Belgium relative to the western Netherlands $\left(0.25 \mathrm{~m} \mathrm{kyr}^{-1}\right.$ over the past $5000 \mathrm{yr}$ ), as could be expected from the relative position of the three areas. At present, the sea-level data from the southwestern Netherlands do not allow detection of non-linear isostatic movements.

The tectonic subsidence of the western Netherlands coastal area relative to Belgium, based here on the altitude of the Eemian sea-level highstand $\left(0.06\right.$ to $\left.0.16 \mathrm{~m} \mathrm{kyr}^{-1}\right)$, is somewhat lower than the value calculated by Kooi et al. (1998, their fig. 4) as an average over the Quaternary period (approximately 0.20 to $0.40 \mathrm{~m} \mathrm{kyr}^{-1}$ ). If real, this difference may imply that the tectonic subsidence rate is not constant over periods longer than $10^{5} \mathrm{yr}$. This issue warrants further study.

The isostatic predictions in the southern Bight of the North Sea and along its eastern coast based on the rebound model of Lambeck et al. (1998) are generally in good agreement with empirical sea-level observations. They show that, particularly during early and middle Holocene times, considerable isostatic crustal movements have occurred over short distances $(<150 \mathrm{~km})$ in this area. This implies that (i) the 
concept of a regionally representative sea-level curve has limited value; each small area of ca. $50 \mathrm{~km}$ across potentially has its own sea-level history, (ii) sea-level data from locations farther apart should not be amalgamated in a single curve or error band, and (iii) the pre-7000 cal. yr BP parts of Dutch sea-level curves that are based upon or biased by the North Sea data discussed and used by Jelgersma (1979) are not appropriate models for the Holocene sea-level rise in the coastal zone of the western Netherlands.

Although some recent studies on the Holocene evolution of the North Sea coast take into account the existence of differential isostatic movements (e.g. Beets and Van der Spek, 2000), the use of sea-level curves based on data from both the North Sea and the Dutch coastal region may lead to an overestimation of the rate of sea-level rise on the western Netherlands coast, especially during the early Holocene (e.g. by more than $2 \mathrm{~m} \mathrm{kyr}^{-1}$, or about $20 \%$ of the total rise for the period between 9000 and $8000 \mathrm{cal}$. yr BP; this can be seen on Fig. 13 by comparing the North Sea curve with the model predictions for IJmuiden). This was demonstrated above for the sea-level curve of Jelgersma (1979) for the Dutch sector of the North Sea, but also may be the case for the German Bight sea-level curve presented by Ludwig et al. (1981). In this respect, it is interesting to note that Van Dijk et al. (1991), based on water-level data from the Dutch river area near Rotterdam, suggested that the part of the sea-level curve of Van de Plassche (1982) older than about $7000 \mathrm{cal}$. yr BP is too low (i.e. too steep, by approximately $1 \mathrm{~m}$ at $7000 \mathrm{cal}$. yr BP).

Models of Holocene coastline evolution, palaeotides and sediment transport should take into account the effects of isostatic rebound on the palaeobathymetry, palaeogeography and sea-level rise in the southern North Sea (see e.g. Gerritsen and Berentsen, 1998; Shennan et al., 2000; Van der Molen and De Swart, 2001). To determine the effects of glacio- and hydroisostatic movements on the Holocene sea-level rise in the Dutch coastal area, new sets of sea-level index points older than at least $7000 \mathrm{cal}$. yr BP should be collected from compact areas $(<50 \mathrm{~km}$ across).

Differential crustal movements between Belgium and the western Netherlands become increasingly difficult to distinguish after ca. 3000 cal. yr BP (Fig. 11). The average value of $0.25 \mathrm{~m} \mathrm{kyr}^{-1}$ for the total movement (tectonic + isostatic) over the past $5000 \mathrm{yr}$ is somewhat higher than the tectonic component of $0.06-0.16 \mathrm{~m} \mathrm{kyr}^{-1}$, but the difference between these two values decreases continuously up to the present day and becomes insignificant during the past few thousand years in view of the error margins on the data. Hence, it is not clear whether isostatic differential movements along the Belgian-Dutch North Sea coast have continued to the present-day.

Acknowledgements This paper benefited from stimulating discussions with and/or comments by C. Baeteman, D. Beets, R. Gehrels, D. Grant, H. Kooi, K. Lambeck, W. Peltier, J. Schokker, T. Törnqvist, R. Van Balen and O. van de Plassche. We greatly appreciated the help of S. Van Heteren and K. Rijsdijk, who provided assistance with and some necessary comments on the North Sea data. We are indebted to A. Long for his help in improving the English of the final text. This is a contribution to the NEESDI (Netherlands Environmental Earth System Dynamics Initiative) programme.

\section{References}

Baeteman C. 1981. De Holocene ontwikkeling van de westelijke kustvlakte (België). Unpublished PhD thesis, Vrije Universiteit Brussel: Brussel.
Baeteman C, Van Strijdonck M. 1989. Radiocarbon dates on peat from the Holocene coastal deposits in West Belgium. Professional Paper Belgische Geologische Dienst 24: 59-91.

Beets DJ, Van der Spek AJF. 2000. The Holocene evolution of the barrier and the back-barrier basins of Belgium and the Netherlands as a function of late Weichselian morphology, relative sea-level rise and sediment supply. Geologie en Mijnbouw 79: 3-16.

Behre KE, Streif H. 1980. Kriterien zu Meeresspiegel- und darauf bezogene Grundwasserabsenkungen. Eiszeitalter und Gegenwart 30: $153-160$.

Behre KE, Menke B, Streif H. 1979. The Quaternary geological development of the German part of the North Sea. In The Quaternary History of the North Sea Oele E, Schüttenhelm RTE, Wiggers AJ (eds). Acta Universitatis Upsaliensis Symposia Universitatis Upsaliensis Annum Quingentesimum Celebrantis 2: 85-113.

Bosch JHA, Cleveringa P, Meijer T. 2000. The Eemian stage in the Netherlands: history, character and new research. Geologie en Mijnbouw 79: 135-145.

Cleveringa P, Meijer T, Van Leeuwen RJW, De Wolf $H$, Pouwer R, Lissenberg T, Burger AW. 2000. The Eemian stratotype locality at Amersfoort in the central Netherlands: a re-evaluation of old and new data. Geologie en Mijnbouw 79: 197-216.

Denys L. 1993. Paleoecologisch diatomeeënonderzoek van holocene afzettingen in de westelijke Belgische kustvlakte. Unpublished PhD thesis, Universitaire Instellingen Antwerpen (UIA): Antwerpen.

Denys L, Baeteman C. 1995. Holocene evolution of relative sea level and local mean high water spring tides in Belgium - a first assessment. Marine Geology 124: 1-19.

Fjeldskaar W. 1994. The amplitude and decay of the glacial forebulge in Fennoscandia. Norsk Geologisk Tidsskrift 74: 2-8.

Gerritsen H, Berentsen CWJ. 1998. A modelling study of tidally induced equilibrium sand balances in the North Sea during the Holocene. Continental Shelf Research 18: 151-200.

Jelgersma S. 1961. Holocene sea-level changes in the Netherlands. Mededelingen Geologische Stichting C-IV. 7: 1-100.

Jelgersma S. 1979. Sea-level changes in the North Sea basin. In The Quaternary History of the North Sea, Oele E, Schüttenhelm RTE, Wiggers AJ (eds). Acta Universitatis Upsaliensis Symposia Universitatis Upsaliensis Annum Quingentesimum Celebrantis 2: 233-248.

Jelgersma S, Oele E, Wiggers AJ. 1979. Depositional history and coastal development in The Netherlands and the adjacent North Sea since the Eemian. In The Quaternary History of the North Sea, Oele E, Schüttenhelm RTE, Wiggers AJ (eds). Acta Universitatis Upsaliensis Symposia Universitatis Upsaliensis Annum Quingentesimum Celebrantis 2: 115-142.

Kiden P. 1995. Holocene relative sea-level change and crustal movement in the southwestern Netherlands. Marine Geology 124: $21-41$.

Kooi H, Johnston P, Lambeck K, Smither C, Molendijk R. 1998. Geological causes of recent $(\sim 100 \mathrm{yr})$ vertical land movement in the Netherlands. Tectonophysics 299: 297-316.

Lambeck K. 1995. Late Devensian an Holocene shorelines of the British Isles and North Sea from models of glacio-hydroisostatic rebound. Journal of the Geological Society of London 152: 437-448.

Lambeck K. 1997. Sea-level change along the French Atlantic and Channel coasts since the time of the Last Glacial Maximum. Palaeogeography, Palaeoclimatology, Palaeoecology 129: 1-22.

Lambeck K, Smither C, Johnston P. 1998. Sea-level change, glacial rebound and mantle viscosity for northern Europe. Geophysical Journal International 134: 102-144.

Lorenz GK, Groenewoud W, Schokking F, Van den Berg MW, Wiersma J, Brouwer FJJ, Jelgersma S. 1991. Heden en verleden-Nederland naar beneden??? Interim rapport over het onderzoek naar bodembeweging in Nederland. Report, Rijkswaterstaat-Rijks Geologische Dienst: Rijswijk-Haarlem.

Ludwig G, Müller H, Streif H. 1981. New dates on Holocene sealevel changes in the German Bight. Special Publication of the international Association of Sedimentologists 5: 211-219.

Menke B. 1988. Die holozäne Nordseetransgression im Küstengebiet der südöstlichen Deutschen Bucht. In Norderhever-Projekt. 1. Landschaftsentwicklung und Siedlungsgeschichte im Einzugsgebiet 
der Norderhever (Nordfriesland). Offa Bücher 66, Karl Wachholtz Verlag: Neumunster; $117-137$.

Morzadec-Kerfourn MT, Delibrias G. 1972. Analyses polliniques et datations radiocarbone des sédiments quaternaires prélevés en Manche centrale et orientale. Mémoires du Bureau de Recherche Géologique et Minière 79: 160-165.

Mostaert F, De Moor G. 1984. Eemian deposits in the neighbourhood of Brugge: a palaeogeographical and sea-level reconstruction. Bulletin Société belge de Géologie 93: 279-286.

Mostaert F, De Moor G. 1989. Eemian and Holocene sedimentary sequences on the Belgian coast and their meaning for sea level reconstruction. In The Quaternary and Tertiary Geology of the Southern Bight, North Sea, Henriet JP, De Moor G (eds). Ministry of Economic Affairs, Belgian Geological Survey: Brussels; 137-148.

Mörner N-A. 1979. The Fennoscandian uplift and Late Cenozoic geodynamics: geological evidence. GeoJournal 3: 287-318.

Mörner N-A. 1980. The northwest European 'sea-level laboratory' and regional Holocene eustasy. Palaeogeography, Palaeoclimatology, Palaeoecology 29: 281-300.

Müller H. 1974. Pollenanalytische Untersuchungen und Jahresschichtenzählung an der eem-zeitlichen Kieselgur von Bispingen/Luhe. Geologisches Jahrbuch A21: 149-169.

Paepe R, Vanhoorne R, Deraymaeker D. 1972. Eemian sediments near Brugge (Belgian coastal plain). Belgische Geologische Dienst Professional Paper 1972/9: 1-12.

Roep ThB, Beets DJ. 1988. Sea level rise and paleotidal levels from sedimentary structures in the coastal barriers in the western Netherlands since 5600 BP. Geologie en Mijnbouw 67: 53-60.

Shennan I. 1987. Holocene sea-level Changes in the North Sea, In Sealevel Changes, Tooley MJ, Shennan I (eds). Basil Blackwell: Oxford; 109-151.

Shennan I, Lambeck K, Flather R, Horton B, McArthur J, Innes J, Lloyd J, Rutherford M, Wingfield R. 2000. Modelling western North Sea palaeogeographies and tidal changes during the Holocene. In Holocene Land-Ocean Interaction and Environmental Change around the North Sea, Shennan I, Andrews J (eds). Geological Society Special Publications 166, Geological Society Publishing House: Bath; 299-319.

Vandenberghe J, Vandenberghe N, Gullentops F. 1974. Late Pleistocene and Holocene in the neighbourhood of Brugge. Mededelingen Koninklijke Academie voor Wetenschappen, Letteren en Schone Kunsten Klasse Wetenschappen 36: 1-77.

Van Dijk GJ, Berendsen HJA, Roeleveld W. 1991. Holocene water level development in The Netherlands' river area; implications for sea-level reconstruction. Geologie en Mijnbouw 70: 311-326.

Van de Plassche O. 1982. Sea-level change and water-level movements in the Netherlands during the Holocene. Mededelingen Rijks Geologische Dienst 36(1): 1-93.

Van de Plassche O, Roep ThB. 1989. Sea-level changes in the Netherlands during the last 6500 years: basal peat vs. coastal barrier data. In Late Quaternary Sea-level Correlation and Applications, Scott DB, Pirazzoli PA, Honig CA (eds). Kluwer Academic Publishers: Dordrecht; 41-56.

Van der Molen J, De Swart HE. 2001. Holocene tidal conditions and tide-induced sand transport in the southern North Sea. Journal of Geophysical Research 106: 9339-9362.

Zagwijn WH. 1961. Vegetation, climate and radiocarbon datings in the Late Pleistocene of The Netherlands. Part I: Eemian and early Weichselian. Mededelingen Geologische Stichting 14: 15-45.

Zagwijn WH. 1983. Sea-level changes in The Netherlands during the Eemian. Geologie en Mijnbouw 62: 437-450.

Zagwijn WH. 1996. An analysis of Eemian climate in western and central Europe. Quaternary Science Reviews 15: 451-469.

Ziegler PA, Louwerens CJ. 1979. Tectonics of the North Sea. In The Quaternary History of the North Sea Oele E, Schüttenhelm RTE, Wiggers AJ (eds). Acta Universitatis Upsaliensis Symposia Universitatis Upsaliensis Annum Quingentesimum Celebrantis 2: 7-22. 